\title{
Cohesion and Coherence of Students' Recount Texts in Indonesia
}

\author{
Arif Suryo Priyatmojo ${ }^{1}$ \\ arifsuryo@mail.unnes.ac.id \\ ${ }^{1}$ English Department, Faculty of Language and Arts \\ Universitas Negeri Semarang, Indonesia
}

\begin{abstract}
This study aimed at analyzing the cohesion and coherence of recount texts and their implication to teaching writing. The data was fifteen recount texts which were non-randomly chosen from the first-grade students of high school in Central Java, Indonesia. This was qualitative research employing cohesion theory by Halliday and Hasan (1976) and thematic progression proposed by Butt et al. (1995). The result of this research showed that most of the cohesive devices employed by the students were personal reference with $58.11 \%$; demonstrative reference and definite article with $7.18 \%$; comparative reference with $0.93 \%$ ), lexical (repetition 22.21\%; synonym 0.66\%; superordinate $0.13 \%$ ), conjunction (temporal conjunction $7.45 \%$; adversative conjunction: $1.33 \%$; additive conjunction $1.06 \%$; causal conjunction $0.66 \%$ ), and ellipsis with $2 \%$. The presuppositions of the presupposed items and presupposing items were achieved anaphorically and cataphorically; most of them were anaphoric. The distances of the presuppositions were in the forms of immediate ties, mediated ties, and non-mediated ties. Furthermore, immediate ties occurred extensively. Based on the analysis, most of the texts were cohesive due to the achievement of presupposing and presupposed items in every sentence of the texts. Then, coherence of the students' recount texts was achieved by employing three kinds of patterns: reiteration/ constant, zig-zag, and multiple thematic progression patterns. Most of the texts were developed by using a reiteration/ constant pattern. Based on the analysis, most texts were not coherent because of the unrelated clauses. As the result, they broke the signposted progression of the texts. The finding was expected to possibly contribute to the process of teaching writing by encouraging the students to create a good text in a cohesive and coherent way.
\end{abstract}

Keywords: cohesion, coherence, recount text, writing, Indonesia

\section{INTRODUCTION}

Writing is significant for some reasons. Firstly, writing is a wonderful idea in which every student can explore his ideas. Based on the Indonesian curriculum, the students by the end of the learning process are supposed to create a text. It is based on the texts that the students are studying. Every text has its social function and lexicogrammatical features. For example, in the first grade of high school, the students produce three kinds of texts - procedure, recount, and narrative. In the written activities, the students are demanded to produce those texts. As a result, they need to have ideas to create the text. The ideas are also based on the generic structure of the texts. It is because a good text should be in good order. Thinking and writing is the next significant reason for writing. The third reason, literate students need writing to encode ideas, opinions, etc. In the Indonesian curriculum, from the school-based curriculum to the newest one called K-13 (curriculum 2013 till present), the teaching and learning process is based on a genre-based approach. Here, the teachers give five phases/ cycles for the students - context building, text modeling and deconstructing, text construction, independent of text construction, and linking to related texts. In the fourth phase, it is the phase the students are to produce a text.

When I observed students in English learning processes with a topic about writing recount text, they seemed to produce unrelated sentences. The students also had problems in organizing ideas systematically. For the worst, they were unable to create a unified paragraph. The paragraph jumped out here and there. It could be concluded that they faced difficulties in producing a cohesive text. It was related to Bamberg (1983) in Wang (2007) that one of the main difficulties was lack of cohesion in the texts 
which contributed substantially to lower scores in tests. Also, a coherent text is also important. It is how the students organize the text by informing the readers where the writer is and is going (Butt et al., 1995). By coherence, the text can be read well by the readers toward interrelated clauses.

Writing activity produces a text (Halliday, 1976). In a text, texture has become the most prominent element that can be achieved by cohesive ties which depend on a lexical and grammatical relationship (Witte \& Faigley, 2008). This research investigated cohesive devices used by the students and the way the texts were organized for some reasons. First, cohesion and coherence are two significances of a text. Then, the study could be used to improve the quality of students' writing. The last, it could develop students' skill in writing.

\section{LITERATURE REVIEW}

\section{Text and Language Teaching}

The orientation of teaching English as a foreign language has changed as stated by Richards (2006) by classifying three phases of language teaching. The first is traditional approaches (up to the late 1960s) that prioritize grammatical competence as the basis of proficiency by giving of repetitive practice and drilling. The techniques used were memorization, question, and answer, drilling, and guided speaking and writing by the use of some methodologies such as audiolingual and structural-situational approach. The second is classic communicative language teaching (the 1970s-1990s), and the last is current communicative language teaching (the late 1990s to the present).

However, due to the need for English for a broader communicative purpose, the orientation has changed into its function. It is now recognized as current communicative language teaching. Studying English as a foreign language is not just studying its certain number of fixed patterns, but the students are supposed to study its purpose and function. It relates to Gerrot and Wignell (1994) that the whole systematic language cannot be explained. The students use language to convey their intended meaning in both spoken and written forms.

\section{Halliday and Hasan Taxonomy}

By cohesion continuity of a text is provided by clause structure and clause complexes which is according to Halliday and Hasan formed by formal ties. It binds one sentence to others (Coulthard, 1994). Cohesion based on Halliday and Hasan (1976) is based on five headings reference, substitution, ellipsis, conjunction, and lexical cohesion.

In addition, they also introduced another taxonomy of how a cohesive tie is classified based on the amount of text spanned by the presupposed and presupposing elements of a given tie. It is called text-span classes. A class is determined by the number of T-units a given cohesive tie spans. The cohesive tie is classified based on function and distance. The illustration as follow (Halliday \& Hasan, 1976: 330-340):

Text Span Classes (Immediate, Mediated,

Remote, Mediated-Remote)

(1) The last word ended in a long bleat, so like a sheep that Alice quite started.

(2) She looked at the queen, who seemed to have suddenly wrapped herself up in wool.

(3) Alice rubbed her eyes and looked again.

(4) She couldn't make out what had happened at all.

(5) Was she in a shop?

(6) And was that really - was it really a sheep that was sitting on the other side of the counter.

(7) Rub as she would, she could make nothing more of it

In Sentence (2), she refers to Alice in the first sentence. It relates to the sentence which immediately precedes it. It is called an immediate tie. The word she in Sentence (4) also refers to Alice in the immediate sentence. She, in Sentence (5) has the target of its presupposition another instance of she, that in (4) and to resolve it we have to follow this through to the occurrence of Alice in Sentence (3). This type is called a mediated tie. Remote ties result when two elements of a tie are separated by one or more intervening T-units. It can be seen from Sentence (6). In the sentence, there is no presupposing or presupposed item. Finally, a tie may be both mediated and remote. For example, she in Sentence (7) does not have any 
presupposition in the sentence (6) but refers back to Sentence (5). Here, the tie is considered remote. At the same time, the presupposed item in (5) is again she, which has to be followed through she in (4) and finally to Alice in (3), so it is also mediated.

\section{Coherence}

Coherence is meant as how a text holds together in the right order with a clear process. It plays an important role in how a paragraph can be read well by readers that consists of interrelated sentences. A good writer needs to inform well about his texts. Also, the readers need to understand the topic and the content of the text. A good text is not only due to cohesiveness but also its organization. A coherent text is organized by keeping the readers well informed about what it is and where it is going (Butt et al. 1995). To do so, grammatical resources are needed to signpost through clauses, clause complexes, and paragraphs. Butt et al. (1995: 90) stated that the first signpost must be at the beginning of a text, paragraph or clause to tells the readers what the writer has in mind as a starting point. The first position in the clause signals to the readers what the message is about. The signpost is called theme and rheme (Halliday, 1994).

\section{Genre-based approach}

The approach used in the teaching and learning process of the Indonesian curriculum is textbased. Competence is based on how the language learners have knowledge about different types of texts. A text, according to Richards (2006) refers to structured sequences of languages in specific contexts and ways. Communicative competence refers to the language learners' skill in using different kinds of spoken and written texts in varied contexts. To enable the students to produce written texts, the teachers should implement the teaching and learning process (genre-based approach) in some phases (Feez \& Joyce, 1998):

Phase 1: Context Building: In this stage, students are given the social context of an authentic model of the text, learn features of cultural context and social function of a given text, and investigate the register of a selected model text by exploring: building knowledge of the topic and social activity, understanding the roles and relationship of the people using the text, and understanding the mode of communication.

Activities related to context building include (1) Presenting the context with pictures, audiovisual materials, realia, excursions, field trips, guest speakers, etc; (2) Establishing the social functions by discussion or surveys, etc; (3) Doing cross-cultural activities by comparing differences of two cultures; (4) Comparing the model text with other similar or different texts.

Phase 2: Modeling and Deconstructing the Text. In this stage, students analyze the structure and language characteristics of given texts and identify similarity and difference of the given text with other texts with the same kinds of texts. Feez and Joyce (1998) stated that text, clause, and expression levels are given in the modeling and deconstruction steps.

Phase 3: Joint Construction of the Text. In this stage, the students begin to build whole types of texts then control the text construction independently. Some activities in this step include questioning, discussing, editing, etc.; Constructing texts; doing Jigsaw, informationgap activities, dicto-gloss, self-assessment, and peer-assessment.

Phase 4: Independent Construction of the Text. In this stage, the students work independently with the text and do performances. Independent construction in writing includes writing tasks which demand that students draft and present whole text.

Phase 5: Linking to related Texts. The students identify what they have studied in the learning activities about other texts with the same context and step to the learning process. Some activities in this step are identifying different texts with varied use and finding other texts with the same topics, and finding language characteristics in the same or different texts

\section{METHODOLOGY}

This research was descriptive qualitative research investigating systematically about facts and characteristics of given subjects. The main objectives of this research were (1) to analyze the 
cohesion of the students' recount texts by analyzing the general features of the cohesive devices of the texts and (2) to analyze the thematic progression of the texts.

\section{Subject and object of the research}

The first-grade students of High School Students in Central Java, Indonesia became the subject. Meanwhile, the object of the study was the students' recount texts. Fifteen recount texts were chosen as the object of the study in a nonrandom way.

\section{Unit of analysis}

The focus of analysis for cohesion was sentence Halliday and Hasan (1976), and coherence was clauses (Butt, et al., 1995).

\section{Technique of Collecting Data}

The students' recount texts were the main data chosen from the students' writing. The steps were as follows:
(1) Fifteen recount texts were used as the object;

(2) The texts were arranged based on the number of sentences the students produced;

(3) The texts were analyzed based on the cohesive devices and how the texts were organized (thematic progression).

\section{Data Analysis}

The identification and classification were conducted to find cohesive devices in the appropriate headings with the analysis sheet that covered some elements as the followings:

(1) Index-serial number

(2) Total number of ties

(3) The reference (or the presupposed item) of the particular cohesive item;

(4) The distance between the cohesive item and the referent - o for an immediate tie, $\mathrm{M}$ for mediated, $\mathrm{N}$ for remote/ non-mediated, and C for cataphoric;

(5) The direction

The example of the analysis of cohesive device could be seen as the following example.

\section{Unforgettable Camping}

When I was in Junior High School, I joined a group of scouting (1). It consisted of two groups (one boy and one girl) every year (2). In grade 8, there is camping at Karanggeneng for 3 days (3). We prepared all enthusiastically (4). We went there by a police truck (5). Wow, it was an unforgettable moment (6).

There, we did many activities such as building a tent, making a fence and clothesline, hiking, cooking, and doing a campfire night (7). On the first day, we just built a tent (8). On the second day, we went hiking (9). Before it, we had to cook by ourselves (10). My group cooked rice, corn soup, and fried sausage (11). Because we cooked it hurriedly, the taste of corn soup was a little salty (12). But we like it because it was made by ourselves (13). After that, we went hiking (14).

It was the most tiring hiking we have ever done (15). We walked approximately $4 \mathrm{~km}$ with some stops for some briefing (16). There were some rambutan trees in the route of hiking (17). One of my friends took it and ate it (18). Because we felt very thirsty, we followed him (19). We took some rambutans and ate them together (20). We were lucky because the owner didn't know it (21).

On a campfire night, we felt very happy (22). We sang a song together, watched a drama, and shared together (23). Not only happy but we felt sad because it was the last night we gathered (24).

On the third day, we tidied up our tent, cleaned the place, and went back (25). I was so happy and I never forget that day because it was unforgettable camping and we didn't take a bath for 3 days (26).

\section{Unforgettable Camping}

\begin{tabular}{lllrrr}
\hline $\begin{array}{l}\text { Sentence } \\
\text { Number }\end{array}$ & $\begin{array}{l}\text { No. of } \\
\text { Ties }\end{array}$ & $\begin{array}{l}\text { Cohesive } \\
\text { Item }\end{array}$ & Type & Distance & Item \\
\hline 2 & 1 & it & R13.6 & o & a group of scouting
\end{tabular}


3

4

5

6

7

8

9

10

11

12

13

14

15

16

17

18

19

20

21

22

23

24

25

26

R: $35 \quad$ S: 0
1 we

2

1

2

3

2

2

1

3

2

4

1

1

2

4

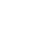

2

2

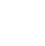

1

1

1
4

4

third

we

I (2x)

that

we
R14.6

R14.6

R22.7

R13.6

R22.7

R14.6

C46.1

R14.6

L1.6

C46.1

R14.6

C41.3

R14.6

R11.8

C33

R14.6

L1.6

C21.1

R14.6

R13.6

C41.1

R14.6

R13.6

R35.9

L1.6

R14.6

R14.6

L1.6

R11.8

R13.6

C33

R14.6

R11.6

R14.6

L1.6

R14.6

R13.6

R14.6

R14.6

R14.6

R13.6

R35.9

C43.1

R14.6

R11.6

R22.6

R14.6 o

M1

o

N2

$\mathrm{M} 1+\mathrm{N} 2$

$\mathrm{M} 1+\mathrm{N} 1$

O

$\mathrm{M} 2+\mathrm{N} 1$

o

o

$\mathrm{M} 3+\mathrm{N} 1$

O

M4+N1

N9

O

$\mathrm{M} 4+\mathrm{N} 2$

o

o

$\mathrm{M} 5+\mathrm{N} 2$

o

o

$\mathrm{M} 6+\mathrm{N} 2$

o

o

o

$\mathrm{M} 7+\mathrm{N} 2$

$\mathrm{M} 8+\mathrm{N} 2$

N1

N16

o

o

M9+N4

o

$\mathrm{M} 10+\mathrm{N} 4$

N2

$\mathrm{M} 11+\mathrm{N} 4$

o

$\mathrm{M} 12+\mathrm{N} 4$

$\mathrm{M} 13+\mathrm{N} 4$

M14+N4

o

O

o

M15+N4

N24

N24

$\mathrm{M} 16+\mathrm{N} 4$ the writer \& group we $\rightarrow$ the writer \& group Karanggeneng camping there $\rightarrow$ Karanggeneng we $\rightarrow$ the writer \& group (S7)

we $\rightarrow$ the writer \& group tent

(S8)

we $\rightarrow$ the writer \& group hiking

we $\rightarrow$ the writer \& group the writer

(S10)

we $\rightarrow$ the writer \& group corn soup

(S12)

we $\rightarrow$ the writer \& group corn soup

(S13)

we $\rightarrow$ the writer \& group

hiking

activity

hiking

we $\rightarrow$ the writer \& group

we $\rightarrow$ the writer \& group

hiking

the writer

rambutan

(S18)

we $\rightarrow$ the writer \& group the writer's friend

we $\rightarrow$ the writer \& group rambutan

we $\rightarrow$ the writer \& group eating rambutan we $\rightarrow$ the writer \& group we $\rightarrow$ the writer \& group we $\rightarrow$ the writer \& group activities on camp activity

(S24)

we $\rightarrow$ the writer \& group

the writer

camping

we $\rightarrow$ the writer \& group 
After that, the texts were analyzed in terms of theme and rheme to see the thematic progression like the following example:

\section{Unforgettable Camping}

(1) When I was in Junior High School,

\begin{tabular}{|l|l|l|}
\hline When & I & was in Junior High School \\
\hline Conj. & \multirow{2}{*}{ Topical } & \\
Tetual & RHEME \\
\hline \multicolumn{2}{|l|}{ THEME } & RHEM \\
\hline
\end{tabular}

(2) I joined a group of scouting

\begin{tabular}{|l|l|}
\hline I & joined a group of scouting \\
\hline Topical & \\
\cline { 1 - 1 } THEME & RHEME \\
\hline
\end{tabular}

(3) It consisted of two groups (one boy and one girl) every year

\begin{tabular}{|l|l|}
\hline It & consisted of two groups (one boy and one girl) every year \\
\hline Topical & \multirow{2}{*}{ RHEME } \\
\hline THEME & RHEM \\
\hline
\end{tabular}

(4) On grade 8, we camped at Karanggeneng for 3 days

\begin{tabular}{|l|l|}
\hline On grade 8 & we camped at Karanggeneng for 3 days \\
\hline Topical & \multirow{2}{*}{ RHEME } \\
\hline THEME & RHEM \\
\hline
\end{tabular}

(5) We prepared all enthusiastically

\begin{tabular}{|l|l|}
\hline We & prepared all enthusiastically \\
\cline { 1 - 1 } Topical & \\
\cline { 1 - 1 } THEME & RHEME \\
\hline
\end{tabular}

(6) We went there by a police truck

\begin{tabular}{|l|l|}
\hline We & went there by a police truck \\
\cline { 1 - 1 } Topical & \multirow{2}{*}{ RHEME } \\
\hline THEME & RHEM \\
\hline
\end{tabular}

(7) Wow, it was an unforgettable moment

\begin{tabular}{|l|l|l|}
\hline Wow & it & was an unforgettable moment \\
\hline Interpersonal & Topical & \multirow{2}{|}{} \\
\cline { 1 - 2 } THEME & RHEME \\
\hline
\end{tabular}

(8) There, we did many activities such as building a tent, making fence and clothesline, hiking, cooking and doing a campfire night

\begin{tabular}{|l|l|}
\hline There & $\begin{array}{l}\text { we did many activities such as building a tent, making fence and clothesline, hiking, } \\
\text { cooking and doing a campfire night }\end{array}$ \\
\hline Topical & \multirow{2}{*}{ RHEME } \\
\hline THEME & RHEM \\
\hline
\end{tabular}


(9) On the first day, we just built a tent

\begin{tabular}{|l|l|}
\hline On the first day & we just built a tent \\
\hline Topical & \\
\hline THEME & RHEME \\
\hline
\end{tabular}

(10) On second day, we went hiking

\begin{tabular}{|l|l|}
\hline On the second day & we went hiking \\
\hline Topical & \multirow{2}{*}{ RHEME } \\
\hline THEME & \\
\hline
\end{tabular}

(11) Before it, we had to cook by ourselves

\begin{tabular}{|l|l|l|}
\hline Before it & we & had to cook by ourselves \\
\cline { 1 - 1 } Conj. & & \\
\cline { 1 - 1 } Textual & Toipcal & \\
\cline { 1 - 1 } THEME & RHEME \\
\hline
\end{tabular}

(12) My group cooked rice, corn soup and fried sausage

\begin{tabular}{|l|l|}
\hline My group & cooked rice, corn soup and fried sausage \\
\hline Topical & \\
\cline { 1 - 1 } THEME & RHEME \\
\hline
\end{tabular}

(13) Because we cooked it hurriedly,

\begin{tabular}{|l|l|l|}
\hline Because & we & cooked it hurriedly \\
\hline Conj. & \multirow{3}{*}{ Topical } & \\
Textual & \\
\hline THEME & RHEME \\
\hline
\end{tabular}

(14) the taste of corn soup was little salty

\begin{tabular}{|l|l|}
\hline the taste of corn soup & was little salty \\
\hline Topical & \multirow{2}{*}{ RHEME } \\
\hline THEME & RHEM \\
\hline
\end{tabular}

(15) But, we like it

\begin{tabular}{|l|l|l|}
\hline But & we & like it \\
\hline Conj. & & \\
\cline { 1 - 1 } Textual & Topical & \\
\cline { 1 - 1 } THEME & RHEME \\
\hline
\end{tabular}

(16) because it was made by ourselves

\begin{tabular}{|l|l|l|}
\hline because & it & was made by ourselves \\
\hline Conj. & & \\
\cline { 1 - 1 } Textual & Topical & \\
\cline { 1 - 1 } THEME & RHEME \\
\hline
\end{tabular}

(17) After that, we went hiking

\begin{tabular}{|l|l|l|}
\hline After that & we & went hiking \\
\hline Conj. & \multirow{2}{*}{ Topical } & \\
Textual & RHEME \\
\hline THEME & \\
\hline
\end{tabular}


(18) It was the most tiring hiking

\begin{tabular}{|l|l|}
\hline It & was the most tiring hiking \\
\hline Topical & \\
\hline THEME & RHEME \\
\hline
\end{tabular}

(19) we have ever done

\begin{tabular}{|l|l|}
\hline we & have ever done \\
\hline Topical & \\
\cline { 1 - 1 } THEME & RHEME \\
\hline
\end{tabular}

(20) We walked approximately $4 \mathrm{~km}$ with some stops for some briefing

\begin{tabular}{|l|l|}
\hline We & walked approximately $4 \mathrm{~km}$ with some stops for some briefing \\
\cline { 1 - 1 } Topical & \multirow{2}{*}{ RHEME } \\
\cline { 1 - 2 } THEME &
\end{tabular}

(21) There were some rambutan trees in the route of hiking

\begin{tabular}{|l|l|}
\hline There & were some rambutan trees in the route of hiking \\
\hline THEME & RHEME \\
\hline
\end{tabular}

(22) One of my friends took and ate it

\begin{tabular}{|l|l|}
\hline One of my friends & took and ate it \\
\hline THEME & RHEME \\
\hline
\end{tabular}

(23) Because we felt very thirsty,

\begin{tabular}{|l|l|l|}
\hline Because & we & felt very thirsty \\
\hline Conj. & & \\
\hline Textual & Topical & \\
\hline Theme & & Rheme \\
\hline
\end{tabular}

(24) we followed him

\begin{tabular}{|l|l|}
\hline we & followed him \\
\hline THEME & RHEME \\
\hline
\end{tabular}

(25) We took some some rambutans and ate them together

\begin{tabular}{|l|l|}
\hline We & took some some rambutans and ate them together \\
\hline Topical & \multirow{2}{*}{ RHEME } \\
\hline THEME & RHEME \\
\hline
\end{tabular}

(26) We were lucky

\begin{tabular}{|l|l|}
\hline We & were lucky \\
\hline Topical & \multirow{2}{*}{ RHEME } \\
\cline { 1 - 1 } THEME & RHEM \\
\hline
\end{tabular}

(27) because the owner didn't know it

\begin{tabular}{|l|l|l|}
\hline because & the owner & the owner \\
\hline Conj. & & \\
\cline { 1 - 1 } Textual & Topical & \\
\cline { 1 - 1 } THEME & RHEME \\
\hline
\end{tabular}


(28) On a campfire night, we felt very happy

\begin{tabular}{|l|l|}
\hline On a campfire night & we felt very happy \\
\hline Topical & \multirow{2}{*}{ RHEME } \\
\hline THEME & RHE \\
\hline
\end{tabular}

(29) We sang a song together, watched a drama and shared together

\begin{tabular}{|l|l|}
\hline We & sang a song together, watched a drama and shared together \\
\cline { 1 - 1 } Topical & \\
THEME & RHEME \\
\hline
\end{tabular}

(30) Not only happy, but we also felt sad

\begin{tabular}{|l|l|l|l|}
\hline Not only happy & but & we & also felt sad \\
\hline Interpersonal & Textual & Topical & \multirow{2}{*}{ RHEME } \\
\hline THEME & RHEME \\
\hline
\end{tabular}

(31) Because it was the last night

\begin{tabular}{|l|l|l|}
\hline Because & it & was the last night \\
\hline Conj. & \multirow{2}{*}{ Topical } & \\
\cline { 1 - 1 } Textual & RHEME \\
\hline THEME & RHEM
\end{tabular}

(32) we gathered

\begin{tabular}{|l|l|}
\hline we & Gathered \\
\hline Topical & \multirow{2}{*}{ RHEME } \\
\hline
\end{tabular}

(33) On the third day, we tidied up our tent,

\begin{tabular}{|l|l|}
\hline On the third day & $\begin{array}{l}\text { we tidied up our tent, cleaned the place and went } \\
\text { back }\end{array}$ \\
\cline { 1 - 1 } Topical & RHEME \\
\hline THEME & RHEM
\end{tabular}

(34) cleaned the place

\begin{tabular}{|l|l|}
\hline we & Cleaned the place \\
\hline Topical & \\
\cline { 1 - 1 } THEME & RHEME \\
\hline
\end{tabular}

(35) and went back

\begin{tabular}{|l|l|l|}
\hline and & we & went back \\
\hline textual & Topical & \multicolumn{1}{|c|}{ RHEME } \\
\hline THEME & RHEME \\
\hline
\end{tabular}

(36) I was so happy

\begin{tabular}{|l|l|}
\hline I & was so happy \\
\hline Topical & \\
\cline { 1 - 1 } THEME & RHEME \\
\hline
\end{tabular}

(37) and I never forget that day

\begin{tabular}{|l|l|l|}
\hline and & I & never forget that day \\
\hline Conj. & & \\
\hline
\end{tabular}




\begin{tabular}{|l|l|l|}
\hline Textual & Topical & \\
\cline { 1 - 1 } THEME & RHEME \\
\hline
\end{tabular}

(38) because it was an unforettable camping

\begin{tabular}{|l|l|l|}
\hline because & It & was an unforettable camping \\
\hline Conj. & & \\
\cline { 1 - 1 } Textual & Topical & \\
\cline { 1 - 1 } THEME & RHEME \\
\hline
\end{tabular}

(39) and we didn't take a bath for 3 days

\begin{tabular}{|l|l|l|}
\hline and & we & didn't take a bath for 3 days \\
\hline Conj. & & \\
\cline { 1 - 1 } Textual & Topical & \\
\cline { 1 - 1 } THEME & RHEME \\
\hline
\end{tabular}

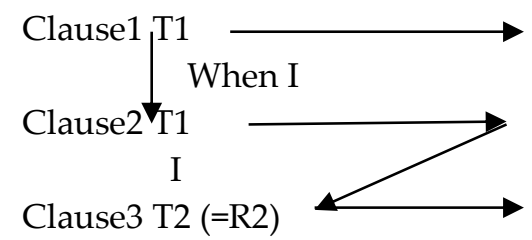

It

Clause4 T3

On ... 8

Clause5,T4 (=R4)

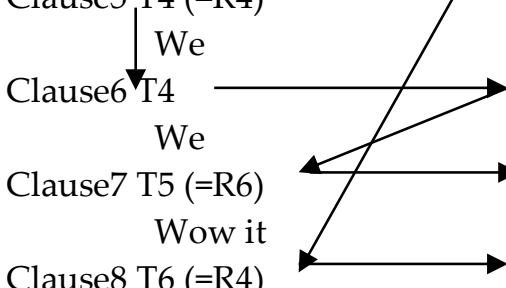

Clause8 T6 (=R4)

There

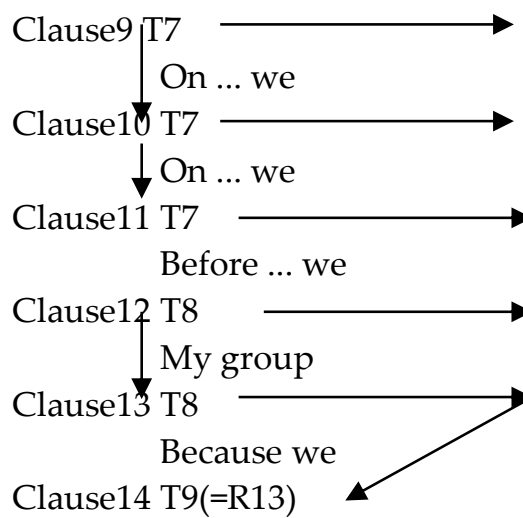

the taste of corn soup

Clause15 T10

but, we

Clause16 T11(=R15)

because it

Clause17 T12

After ... we

Clause18 T13(=R17)
$\mathrm{R} 1$

was junior high school

R2

joined a group of scouting

R3

consisted ... year

$\mathrm{R} 4$

we ... days

R5

prepared ... enthusiastically

R6

went ... truck

R7

was ... moment

R8

we ... night

R9

built ... tent

R10

went ... hiking

R11

had ... ourselves

R12

cooked ... sausage

R13

cooked it hurriedly

R14

was little salty

R15

like it

R16

was ... ourselves

R17

went hiking

R18 


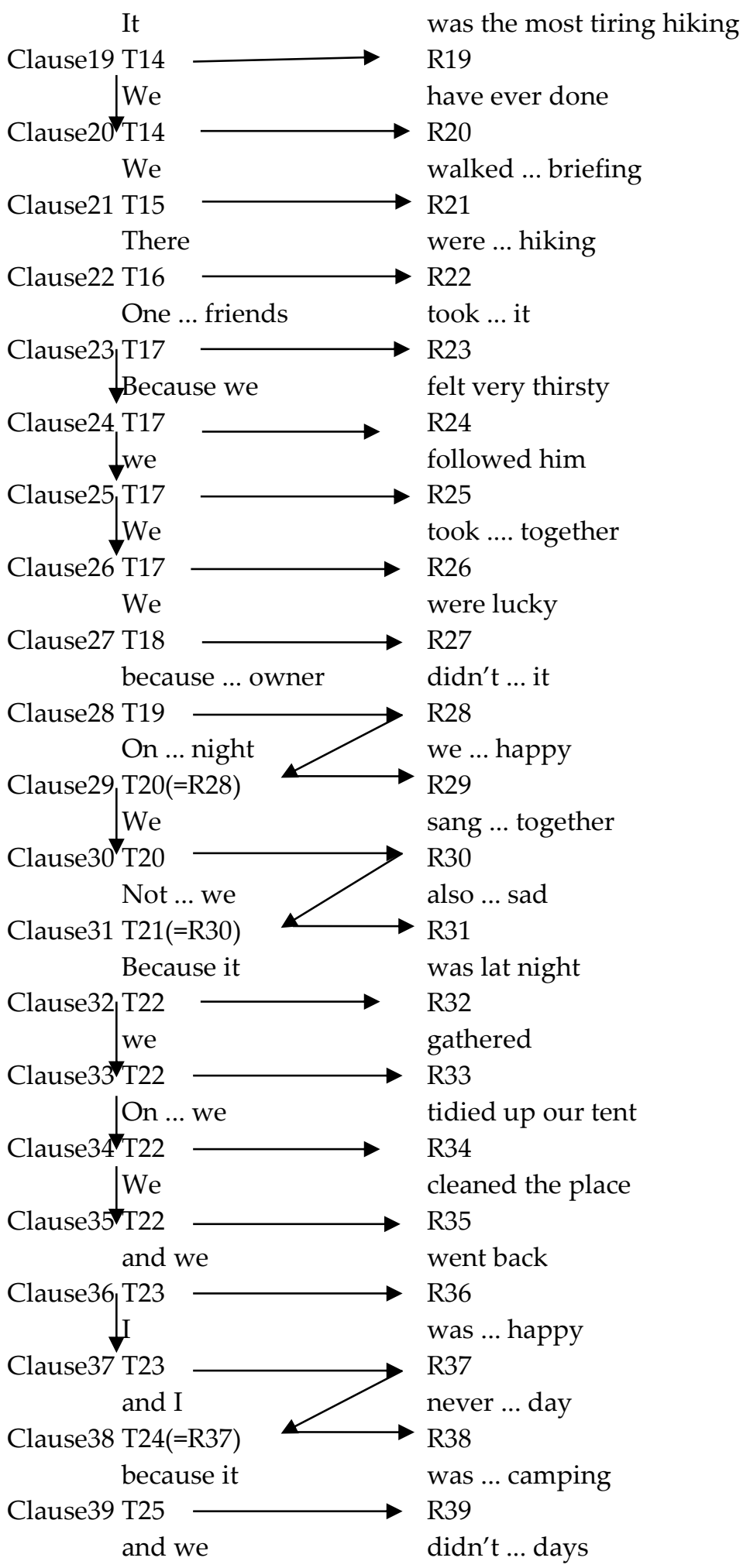

\section{RESULT AND DISCUSSION}

\section{Cohesion}

Cohesion of the students' writings was analyzed by applying Halliday and Hasan's framework. Based on their suggestions, the first thing to do was by indicating how many cohesive ties instances of a cohesive element within the sentence. Then, for every type of tie we specified what type of cohesion involved in terms of reference, substitution, conjunction, ellipsis, and lexical cohesion. Thirdly, for every tie, we specified whether this kind of tie was immediate or non-immediate. If it was non-immediate, it 
was whether mediated, remote or both mediated and remote. There had to be an assigning numerical value to each instance. Table 1 . summarized the data analysis.

Table 1

Students' Cohesive Devices

\begin{tabular}{|l|l|l|l|l|}
\hline No & Devices & Number & $\%$ \\
\hline \multirow{2}{*}{1} & \multirow{2}{*}{ Reference } & Personal reference & 437 & $58.11 \%$ \\
\cline { 3 - 5 } & & Demonstrative reference \& definite article & 54 & $7.18 \%$ \\
\cline { 3 - 5 } & & Comparative reference & 7 & $0.93 \%$ \\
\hline \multirow{2}{*}{2} & \multirow{2}{*}{} & Additive conjunction & 8 & $1.06 \%$ \\
\cline { 3 - 5 } & & Adversative conjunction & 10 & $1.33 \%$ \\
\cline { 3 - 5 } & & Causal conjunction & 5 & 0.66 \\
\cline { 3 - 5 } & & Temporal conjunction & 56 & $7.45 \%$ \\
\hline 3 & Lexical & Repetition & 167 & $22.21 \%$ \\
\hline & & Synonym & 5 & $0.66 \%$ \\
\hline & & Superordinate & 1 & $0.13 \%$ \\
\hline 4 & Ellipsis & & 2 & $0.27 \%$ \\
\hline 5 & Substitution & & - & - \\
\hline & Total & & 752 & $100 \%$ \\
\hline
\end{tabular}

Most of the students employed three kinds of cohesive devices. Those three ties occurred more frequently than others. They were a reference, conjunction, and lexical cohesion. The reference occurred more frequently than others, numbering 498 . Then, it was followed by lexical cohesion with 173 occurrences and conjunction with 79 occurrences. There were only two ellipses on the table. In writing a recount text, the students were supposed to use grammatical devices that involved reference, lexical, conjunction, and also two other cohesive devices - ellipsis and substitution. From the overall texts, we concluded that most students could produce cohesion of the texts. Meanwhile, 4 students produced intervening sentences in their texts by which the texts be less cohesive. By the existence of those intervening sentences, there were no presupposing and presupposed items in the sentences. This leads the texts to be weak in cohesion. Halliday (1994) also argued that the use of ellipsis and substitution is the prominent characteristic of spoken language. The students also had difficulty in employing substitution and ellipsis since they are the realization of grammatical relation in the level of lexicogrammar. They were considered more confusing rather than reference, lexical, and conjunction.

\section{Coherence}

Meanwhile, the flow of information in a sentence from theme to rheme is crucial in achieving communicative effectiveness in a message. The exchange of information between successive theme and rheme pairings in a text is called thematic progression (Eggins, 1994). Thematic progression contributes to the coherent development of a text, that is to say, in a coherent text the distribution of given and new information needs to follow certain patterns. There are several main types of thematic progression, which depends on different text types. As stated before, to analyze the thematic progression from the students' recount texts we used the theory from Butt et al. (1995). Here is the table of the thematic progression patterns employed by the students in the 15 students' texts.

Table 2

Thematic Progression Produced by the Students

\begin{tabular}{|c|c|c|c|c|c|c|c|c|c|c|c|c|c|c|c|}
\hline \multirow{3}{*}{$\begin{array}{l}\text { Thematic } \\
\text { Pattern }\end{array}$} & & \multicolumn{14}{|c|}{ Students' Texts } \\
\hline & 1 & 2 & 3 & 4 & 5 & 6 & 7 & 8 & 9 & 1 & 1 & 1 & 1 & 1 & 1 \\
\hline & & & & & & & & & & 0 & 1 & 2 & 3 & 4 & 5 \\
\hline
\end{tabular}




\begin{tabular}{llllllllllllllll}
\hline Constants & 6 & 1 & 1 & 1 & 1 & 9 & 1 & 1 & 1 & 5 & 1 & 1 & 1 & 1 & 1 \\
& & 3 & 2 & 2 & 8 & & 0 & 3 & 6 & & 0 & 4 & 5 & 4 & 5 \\
\hline Zig-zag & 5 & 3 & 8 & 2 & 8 & 1 & 6 & 3 & 4 & 5 & 4 & 2 & 4 & 6 & 8 \\
& & & & & & 1 & & & & & & & & & \\
\hline Multiple & 4 & 5 & 8 & - & 1 & 7 & 3 & - & - & 7 & 1 & 2 & 4 & 9 & 5 \\
\hline Total of & 1 & 2 & 3 & 2 & 4 & 3 & 2 & 3 & 3 & 3 & 3 & 3 & 3 & 4 & 3 \\
clauses & 9 & 7 & 1 & 5 & 4 & 9 & 7 & 6 & 6 & 4 & 7 & 4 & 2 & 3 & 9 \\
\hline
\end{tabular}

From the table above, the students mostly employed thematic progression pattern in the form of constant or reiteration. The constant thematic pattern is the way a writer repeats the theme from the previous theme directly. The theme produced by the students mostly were the repetition of pronoun ( $I$, she, he, it, they, we). One of the reasons stated by Cahyono (2009) is that the students find it easier to use pronouns in their writing by repeating one clause to another at the beginning of the clause. Then, the second thematic progression pattern used by the students in their texts was zig-zag/ crossreferential thematic progression. It means that the students put the rheme as the new theme in the subsequent clause. Finally, the last pattern used by the students was in the form of multiple thematic progression. Furthermore, the number was not as many as constant and zig-zag patterns. The students did not improve their texts well. From the elaboration and the given table above, the numbers of clauses and thematic progression patterns were not balanced. It means that there were many clauses unrelated to one another. The students often introduced some new themes at the beginning of the clause without any relation with other clauses and they broke the well-signposted progression of the text. It can be concluded that most of the recount texts produced by the students were not coherent.

\section{CONCLUSION}

To create cohesion of the texts, there were three cohesive devices that most of the students employed; personal pronoun, repetition, and temporal conjunctions. It indicated that the students created recount texts in a good structure since the personal reference and temporal conjunction are the lexicogrammatical features of a recount text. The cohesive devices were frequently used as personal references. It occurred 437 times or $58.11 \%$. The second occurrence was repetition with 167 times or $22.21 \%$. The third was the temporal conjunction with 56 occurrences or $7.45 \%$. Then, the adversative conjunction occurred 10 times or $1.33 \%$. Next, additive conjunction occurred eight times or $1.06 \%$. The next device was a comparative reference with seven times or $0.93 \%$. Then, the occurrences of causal conjunction and synonym were five times each or $0.66 \%$. Ellipsis also occurs two times or $0.27 \%$. The last device which existed and became the fewest number was superordinate. It only occurred once or $0.13 \%$. Those numbers were based on the total cohesive devices found in the texts.

Then, from all ties between presupposing items and presupposed items, most of them were in the form of anaphoric and cataphoric ways. Furthermore, the relations were mostly those of anaphoric relations. The function of anaphoric and cataphoric relations is to create cohesion in the text and also to create the meaning of the text. The distance of the presuppositions that existed between ties in the texts was varied such as immediate, mediated, and non-mediated ties. On the one hand, the students could produce cohesion of the texts. On the other hand, some intervening sentences occurred in some texts. These intervening sentences could make the texts less cohesive. Furthermore, most of the texts produced by the students were cohesive.

Then, the students developed their texts by employing reiteration or constant thematic progression pattern. The second pattern employed was a zig-zag pattern. The least was the multiple thematic progression pattern. Based on the analysis of the way students developed the text in thematic progression, most of the texts were not coherent. There were many occurrences of unrelated clauses in the texts unrelated to the previous themes or rhemes. They appeared as new themes in the clauses, but they broke the signposted progression of the text. It means that the students failed to create unified related to 
one another from the beginning to end. As a result, most of the texts were not coherent. There were only two texts considered coherent due to fewer intervening sentences.

One implication of the present study was that if cohesion is better understood, coherence is better taught. At present, coherence is taught, explicitly or implicitly, either through exercises, classroom instructions, or comments to students' texts. This research could also contribute to students in the writing activities because it gives the view to the students to write a cohesive and coherent text. The teachers could also improve the strategies in teaching writing based on the weaknesses of the students. Based on the finding, teaching coherence becomes a concern as the students are weak in creating a coherent text. They seemed to have more difficulties in producing a coherent text. Small exercises to produce a coherent text can start from producing coherent sentences, short paragraphs, and a text.

\section{REFERENCES}

Aghdam, S.H., \& Hadidi, Y. (2015). Cohesion and coherence in political newspaper and discussion sections of academic article. International Journal on Studies in English Language and Literature, 3(3), 11-22

Bamberg. (1983). What makes a text coherent? College Composition and Communication, 34(4), 417-429.

Butt, D., Fahey, R., Feez, S., \& Spinks, S. (Eds). (2000). Using Functional Grammar: An explorer's Guide ( $\left.2^{\text {nd }} e d\right)$. National Centre for English Language Teaching and Research Macquaire University.

Cahyono, S.P. (2009). Applying textual metafuction in EFL writing: A method to teach writing. https://repository.dinus.ac.id/docs/ajar/Applyi ng_Textual_Metafunction_in_EFL_Writing.p $d f$

Coulthard, M. (1994). Advanced in Written Text Analysis. Routledge

Dossoumou, A.M., Mehouenou, M.S., \& Koukpossi, A.O. (2018). Appraising the impact of cohesion and coherence in Benin SS3 EFL learners' writing productions: A linguistics perspective. International Journal of Lingustics, Literature and Culture, 4(5), 4154 https://doi.org/10.21744/ijllc.v4n5.293

Emilia, E., Habibi, N., \& Bangga, L.A. (2017). An analysis of cohesion of exposition texts: An Indoneisan context. Indonesian Journal of Applied Linguistics. 7(3), 515523.https//:dx.doi10.17509/ijal.v7i3.9791

Feez, S., \& JOYCE, H. (998). Text-Based Syllabus Design. AMES

Gerrot, L., \& Wignell, P. (1994). Making sense of functional grammar. Antipodean Educational Enterprises

Halliday, M.A.K. (1994). An Introduction to functional Grammar(2 ${ }^{\text {nd }}$ ed.). Edward Arnold.

Halliday, M.A.K., \& Hasan, R. (1976). Cohesion in English. Longman

Isti'anah, A., Putri, S.P., \& Permata, A.G. (2020). Cohesion in jurnal articles on applied linguistics: The case of conjunction 'thus". Journal of Applied Studies in Language, 4(1), 68-78. http://ojs.pnb.ac.id/index.php/JASL

Ong, J. (2011). Investigating the use of cohesive devices by Chinese EFL learners. Asian EFL Journal, 13(3), 42-65

Richards, J.C. (2006). Communicative language teaching today. Cambridge University Press

Suwandi. (2015). Coherence and cohesion: An analysis of the final project abstracts of the undergraduate students of PGRI Semarang. Indonesian Journal of Applied Linguistics, 5(2), 253-256. https:// dx.doi.org/10.17509/ijal.v5i2.1349

Wang, L. (2007). Theme and rheme in the thematic organization of text: Implications for teaching academic writing. Asian EFL Journal, 9(1).

Witte, S.P., \& Faigley, L. (2008). Coherence, cohesion and writing quality. College Composition and Communication, 32(2). 